\title{
The right to the future and chrono-logics otherwise: Resisting governmentality's temporal conduct
}

OÑATI SOCIO-LEGAL SERIES VOLUME 10, IsSUe 6 (2020), 1289-1316: GOVERNING THE POLITICAL: LAW AND THE POLITICS OF RESISTANCE

DOI LINK: HTTPS://DOI.ORG/10.35295/OSLS.IISL/0000-0000-0000-1051

RECEIVED 21 SEPTEMBER 2018, ACCEPTED 06 JuNE 2019

\section{HEIDI ANDREA RESTREPO RHODES* (D)}

\section{Abstract}

This paper attends to differing praxes of futurity circulating in Colombia, both in dominant and subaltern forms. It first considers temporality as an apparatus of governmentality, raison d'état, and settler colonial logics of violence deployed in the service of late liberalism, capitalist endeavor, and the so-called "peace dividend." In contrast, it elaborates two distinct rights claims that counter official state claims on the future: the principle of the right to a distinct vision of the future in Colombia's black Pacific social movement; and the legal claim of the right of future generations in a historic 2018 lawsuit brought against the government by several youth from diverse regions across the country. These claims pose what I name as a "chrono-logics" otherwise - temporal alterities that refuse the logics of settler colonial temporality and insist on an ecology of relations that pursue the survival and flourishing of diverse lifeworlds and futures.

\section{Key words}

Futurity; governmentality; human rights; liberalism; temporality

\section{Resumen}

Este artículo se ocupa de diferentes praxis de futuridad que circulan en Colombia, tanto en formas dominantes como subalternas. En primer lugar, toma en consideración la temporalidad como un aparato de la gubernamentalidad, la razón de Estado, y las lógicas de violencia del colonialismo que se despliegan al servicio del liberalismo tardío, el empeño capitalista y el así denominado "dividendo de la paz". Elaboramos dos reivindicaciones de derechos que contradicen las proclamas estatales oficiales sobre el futuro: el principio del derecho a una visión distinta del futuro en el movimiento social negro pacífico de Colombia; y la pretensión jurídica del derecho de

\footnotetext{
* Doctoral Fellow, Political Theory, The Graduate Center, City University of New York. Contact details: The Graduate Center, CUNY, 365 Fifth Avenue, Room 5202, New York, NY 10016. Email addresses: heidiarhodes@gmail.com / hrhodes@gradcenter.cuny.edu
} 
las generaciones venideras en una demanda judicial histórica de 2018 que interpusieron jóvenes de diversas regiones del país contra el gobierno. Estas reivindicaciones plantean lo que denomino una "crono-logía" de otra manera - alteridades temporales que rechazan la lógica de la temporalidad colonialista y que insisten en una ecología de relaciones que persiguen la supervivencia y el florecimiento de diversos mundos y futuros.

\section{Palabras clave}

Futuridad; gobernabilidad; derechos humanos; liberalismo; temporalidad 


\section{Table of contents}

1. Introduction: Governmentality and temporal conduct in Colombia

2. Context: Histories and futures

3. The right to a distinct vision of the future: Black Colombian epistemologies and chrono-logical alterity

4. Litigating the future and the right of generations to come

in the Colombian Amazon

5. Conclusion. Chrono-logics otherwise: The future out of bounds

1305

References

1308 


\section{Introduction: Governmentality and temporal conduct in Colombia}

With one of the largest humanitarian crises in the Western Hemisphere, Colombia's subaltern populations have for decades collectively organized against the onslaught of disappearances, extrajudicial killings, torture, sexual violence, forced displacement, and other human rights violations perpetrated by the Colombian Armed Forces, paramilitaries, and insurgent groups. Colombia's black and indigenous populations have been disproportionately affected by these violations, as their communities reside in territories coveted for their strategic location in the context of the armed conflict and drug trade routes, as well as for their biodiversity, which has drawn multinational development and resource extraction interests. Where coloniality and capitalism converge, state discourse has framed the targeting of these communities through counterinsurgency and national security policy, paving way for political violence as a tool of discipline, death, and both cultural and economic assimilation - enacted in the name of democracy and national progress. While the country has seen advances in addressing both the rights of victims and ethno-racial rights, the implementation of legislation meant to attend to the needs of these communities has been limited (see, for example, Paschel 2016). Even as the ethno-racial rights framework in Colombia has shifted the terrain of rights-based justice by moving away from a universal liberal subject toward the particular demands and needs of indigenous and black populations, multiple constraints remain, resulting in continued violence against Colombia's subalterns, even in the post-Peace Accord moment.

Given this context, what envisionings, articulations, and implementations of programming and policy are shaping what is conceived of as progress toward peace in talking about "the future of Colombia"? Whose future is the future of the nation amid a deep genealogy of armed conflict and counterinsurgency as apparatuses of biopolitical governmentality and its imbrications in late liberal capitalism and coloniality? ${ }^{1}$ What are the chrono-logics, or logics of temporality - of past, present, and future; the physics, microphysics, and metaphysics of time - that are sanctioned by the Colombian State and its endeavors proliferating the hegemonic imaginary of dominant Colombian society? ${ }^{2}$

While there is a vast literature, in both English and Spanish, elaborating on the effects of biopolitical governmentality across Colombia's history, the focus has been primarily on the geospatial and political forces effecting the conduct of conduct and its subjectivating

\footnotetext{
${ }^{1}$ Foucault's notion of governmentality refers to the tendency in Western history toward the form of power known as government, which has led to the cultivation of specific governing apparatuses and forms of knowledge through the ensemble of "institutions, procedures, analyses and reflections, calculations, and tactics" that have "the population as its target, political economy as its major form of knowledge, and apparatuses of security as its essential instrument" (Foucault 2007, 108). Further, he writes, of governmentality: "The exercise of power consists of 'conduct of conducts' (...)" (Foucault 1994, 237) wherein "'[g]overnment did not refer only to political structures or to the management of states; rather it designated the way in which the conduct of individuals or of groups might be directed (...) to govern in this sense, is to structure the possible field of action of others" (Foucault 1983, 221).

2 Denise Ferreira da Silva has critiqued the hegemonic "socio-logics" of western law and its universal, liberal subject of right as one which, among other factors on which she elaborates, is organized through causal, contingent, linear, teleological temporality - made possible through the science of life, the science of man, and the sociology of race relations (Ferreira Da Silva 2010). I use the term "chrono-logics" throughout this paper both in a nod to her work, as well as a way to specifically attend to the temporal element of the sociological.
} 
influences. ${ }^{3}$ The literature on the role of the chrono-logics at play in governmentality's temporal conduct of conduct in Colombia is growing, but more nascent. ${ }^{4}$ Aiming to contribute to the archive of scholarship on Socio-Legal Studies, Future Studies, and Decolonial Thought on Colombia, this paper attends to differing praxes of futurity circulating in Colombia, both in dominant and subaltern forms. It begins by considering temporality as an apparatus of governmentality, raison d'état, and settler colonial logics of violence deployed in the service of late liberalism, capitalist endeavor, and the socalled "peace dividend." In contrast, it elaborates two distinct rights claims that counter official state claims on the future. Arising out of Colombia's human rights, social, and environmental, justice struggles, these counter-claims are notable as challenges not only to the law's normative framing of the liberal citizen-subject of right, but also to the dominant logics of temporality circulating to construct and uphold national historical narratives and their ensuing aims for national futures and the coloniality they uphold. First, this paper considers the interventions made through black Pacific social movement knowledge-building and epistemologies seeking a right to cultural objection. Specifically, where the right to territory and to ontological and political difference converge with the principle of the right of to a distinct collective vision of the future. Second, this paper examines a 2018 lawsuit and historic ruling by the Colombian Supreme Court, which bases its claims on the right of futurity for the litigants and for generations to come, also following a growing trend of assigning legal personhood to natural elements (in this case, the Amazon Forest).

Such rights and their claims exceed the boundaries of liberal sovereignty of the subject and its right under the raison d'état, and its Official Histories and Futures. They challenge the pressures of governmentality, its chrono-logics organizing the temporal conduct of conducts, introducing into the linearity of settler colonial temporality a switch-point divergence, or wholly other trajectory, by which other futures are rendered possible in the imagination and collective material life. These claims pose what I name as a chronologics otherwise - temporal alterities that refuse the logics of settler colonial temporality and insist on an ecology of relations that pursue the survival and flourishing of diverse lifeworlds and futures. These approaches to rights necessarily redefine the relationships between the state and civil society's diversely constituted population, reconfiguring: processes of subjectivation and governance which underwrite relations of power; the logics of sociality and possibilities for conviviality; and the grounds for opening political life to counter-hegemonic envisionings of freedom and future, the what is to come.

\section{Context: Histories and futures}

In a 2014 interview on CNN's Global Public Square, Colombian President Juan Manuel Santos was asked to speak on what Colombia's future might hold. His emphasis on

\footnotetext{
${ }^{3}$ In English, see for example, Echavarría 2010, Rozema 2011, Coleman 2013, Zeiderman 2013, Arboleda 2015, and Counter 2018. In Spanish, see for example, Martínez Posada 1998, Maldonado 2003, Restrepo 2004, Castro-Gómez 2004, 2007, Martínez Posada and Neira Sánchez 2009, Antonelli 2011, Pedraza 2011, 2012, Pérez González 2014, and Restrepo Espinosa 2015. See also, the annual Coloquio LatinoAmericano de Biopolítica (Latin American Colloquium of Biopolitics).

${ }^{4}$ See for example, Castro-Gómez and Grosfoguel 2007, Escobar 2007, Zeiderman 2016, Loaiza Cano 2016, Ortega 2016, Chaparro Silva 2018, Rähme 2018, and Villegas Correa 2018. See also the broader international/Latin American Grupo de Temporalidad, which is part of the IberConceptos Proyecto y Red de Investigación en Historia Conceptual Comparada del Mundo Iberamericano (see IberConceptos 2012).
} 
"sound economic growth coupled with a business climate that concentrates on investment, entrepreneurship and innovation" mirrors the most common representations in the mainstream media of the benefits of the country's peace process, making Colombia "the world's next venture nation" ripe to attract companies and investors toward developing "new technologies and markets" (Zakaria 2014). Further, suggesting Colombia as Latin America's Silicon Valley, Santos names economic growth as a major indicator in the consolidation of peace, aided by the trade flows enabled by the Pacific Alliance, and generating Colombia's greater capacity to benefit from and contribute to global competitiveness. Other sources reflect this ethos, emphasizing the peace process as a move toward "fiscal management and reduced risk" (World Bank 2018) and a maturing market with thriving industrial, agricultural, and tech sectors ripe for foreign investment (Jaramillo 2017). Further, dominant discourse on Colombia's future underscores the potential peace dividend, as, along with increasingly viable domestic markets, heightened security across the territory ushers in "fewer terrorists and more eco-tourists" (The Economist 2017) as well as opens room for more rural development projects on land which, under armed conflict, had "wasted potential" for production and profit (Food and Agriculture Organization of the United Nations - FAO - 2016).

Underlying these notions is a national narrative of a more stable military security apparatus ensuring peace through demobilizing internal insurgent groups (primarily the FARC so far) deemed enemies of the state. The conflation of human rights defenders with armed insurgents has led to the treatment of human rights advocacy and civil resistance as insurgency. Insofar as communities organize against multinational megadevelopment and extractivist projects, and the military and paramilitary violence on which they rely, political activity intervening on private and foreign investment (the mediums advancing the potential dividends of peace) is framed as a threat to peace and security, and thereby, to Colombia's future. The Peace Agreement compromised land reform agreements that stray from the FARC's foundational demands to redistribute land to peasants and abolish large landholdings, prioritizing instead social and economic development, as well as the return of private property to landholders. But indigenous and Afro-Colombian groups feel insecure in the implementation of the policies laid out, as multinationals continue to encroach on their land without consultation with their communities, threatening collective and individual ancestral land entitlements (Bilotta 2017).

Documented activists killed in Colombia: 2015 - 41; 2016 - 116; 2017 - 191; 2018 - 252 (Instituto de Estudios para el Desarrollo y la Paz - IndePaz - 2019); and at least 51 in the first four months of 2019 (UN Human Rights 2019). Further, the UN reports that three out of four documented killings of human rights defenders across the globe in 2017 took place in the Americas (Reuters in Bogotá 2017). Another source counts 423 killed between January 2016 and November 2018 (Defensoría del Pueblo de Colombia 2018); with 560 acts of aggression against human rights leaders in 2017, that not only put their lives and physical integrity at risk, but impeded their work (Osorio Granados 2018). Not altogether inconsistent with statistics on who was perpetrating these forms of violence previous to the peace process (which placed the Colombian military and paramilitary forces together as $75-85 \%$ responsible for human rights abuses), civil society groups have documented these more recent acts of aggression taking place mostly at the hands of 
paramilitary or BACRIM (59\%), with unidentified actors following (39\%); Colombia Armed Forces (9\%); and insurgent groups responsible for less abuses than in previous years (at less than 1\%) (Somos Defensores 2017). It is no surprise then, that communitybased organizations fighting for social justice make an emphatic distinction marking Colombia's contemporary political environment as post-Peace Accords, but not postconflict. ${ }^{5}$

As noted above, most of the recent killings are perpetrated by off-shoots of the previously demobilized paramilitary forces, which were officially disbanded by Law 975 in 2005 and its associated DDR ${ }^{6}$ process in 2006, but unofficially reconfigured into what the Colombian government has labeled "criminal gangs" (bandas criminales, or BACRIM). Critics of the paramilitary demobilization process called Law 975 an amnesty law that effectively upheld impunity for the thousands of systematic killings, enforced disappearances, forced displacement, torture and sexual violation perpetrated by the paramilitary forces - often in collusion with, or with logistical support from the Colombian military and police forces. Further, many human rights groups contend that the demobilization process was a performative act that gave the global community the illusion of the state's peace and human rights efforts, while allowing paramilitary networks to maintain their financial resources and geographical holds. While the BACRIM constitute a third generation of drug trafficking organizations, they have in many ways replaced the function of the paramilitaries, being paid to terrorize the population, and more specifically union laborers, land reform activists, and social movements, in the service of national and multinational capital interests (McDermott 2014). In fact, all but one of the BACRIM that emerged in the post-demobilization period stemmed from the AUC, Colombia's largest and most notorious paramilitary organization. ${ }^{7}$

The ongoing threats and assassinations faced by black, indigenous, and mestizo rural populations in the struggle for their rights continue to urge questions regarding for whom peace and security are being actualized, and toward what kind of, and whose futures? If the rights of the liberal citizen-subject are contingent upon acquiescence to, and participation in, temporal regimes geared toward cultivating the nation's future as one of a proliferating and thriving neoliberal economy, then those resisting the genocidal forms of violence in the wake of its machinations continue to be left without de jure and de facto rights, both as recourse to legal remedy, and as the freedom to enact or cultivate self-determined futures. The refusal to comply with the temporal conduct necessitated by the market and its technologies of securitization, are responded to with criminalization and the stripping of rights.

\footnotetext{
${ }^{5}$ According to Héctor Marino Carabalí, black human rights leader, co-founder and legal representative of the victims' rights group, Asociación Renacer Siglo XXI, in Northern Cauca, Colombia; co-founder and coordinator for the Committee of Human Rights of the Municipality of Buenos Aires; speaker for the National Coordination of Afro-Descendant Organizations and Communities (CONAFRO); and national delegate for Marcha Patriótica.

${ }^{6}$ DDR: Demobilization, Disarmament, and Reintegration Program (personal communication November 2017).

7 AUC: Autodefensas Unidas de Colombia, or the United Self-Defense Forces of Colombia. The AUC allegedly demobilized in 2006, but evidence of their continued activity and human rights abuses was documented as early as 2008 (Stanford University Mapping Militants Project 2015).
} 
Indeed, as intimated by ProColombia, the official website and program of Colombia's Ministry of Commerce, Industry, and Tourism, to be for Colombia (with the motto: "all for a new country") is to be aligned with national efforts at exports, tourism, investment, and country brand. The website highlights eight cities that were named "Cities of the Future" due to their cost effectiveness and foreign direct investment strategies. ${ }^{8}$ Underlying this messaging are the discursive and material, legal and socio-political implications that to stand against free trade and its economic arrangements is to be against Colombia and its future of economic prosperity, peace, and security, and to be stuck in a past of instability, inefficiency, and conflict. ${ }^{9}$ Dissent is itself marked as regression: futures imagined otherwise and outside of capital and its temporal regimes are deemed immature and contrary to national progress, and ultimately, are criminalized.

\section{The right to a distinct vision of the future: Black Colombian epistemologies and chrono-logical alterity}

On January 27, 2018, Afro-Colombian human rights leader Temístocles Machado was assassinated in the parking lot where he worked in the Pacific port city of Buenaventura, in Colombia's Valle del Cauca region. Known and admired as a decades-long activist and human rights leader fighting for collective rights and land reform, including as part of the Proceso Comunidades Negras (PCN, Black Communities Process), ${ }^{10}$ Machado was shot once in the head and twice in the body by yet unidentified perpetrators. He had been receiving death threats for his organizing work, and his death added to the growing list of human rights defenders being killed in Colombia, despite the ongoing Peace Process efforts of the Colombian government (Carrillo 2018, and Ciurlizza 2018).

Contrary to hegemonic discourse on race in Colombia, racism has been an active force in the experience of the armed conflict, disproportionately affecting black and indigenous Colombians, many of whom reside in territories desired by capital interests for the potential of their biodiverse resources to be extracted and converted to raw material and export production, as well as the land's speculative potential for megadevelopment projects. While Afro-Colombians constitute about $20 \%$ of the national population, they make up at least $30 \%$ of the internally displaced population of almost eight million, and suffer a disproportionately negative impact regarding a variety of

\footnotetext{
${ }^{8}$ Colombia's "Cities of the Future" were named thus in Financial Times fDi Magazine's Cities of the Future of the Americas, and include Bogotá, Cali, Cartagena De Indias, Medellín, Neiva, Pereira, Barranquilla, and Ibague (Financial Times, cited in ProColombia 2018).

9 There is a significant amount of documentation, for instance, on the labelling of human rights defenders, activists, community leaders, and peaceful civil society mobilizations, by political leaders and public officials, as being guerrilla fighters, terrorists, anti-development, and the state's internal enemy. Such labelling contributes to the arbitrary detentions and killings perpetrated in the name of a peaceful and developed future for the country. "At particular risk are defenders that support policies derived from the [Peace] Agreement, such as the Comprehensive Program for Substitution of Illicit Crops (PNIS) and that claim land restitution" (Forst 2018, 18). Further, "defenders might be prosecuted for the crime of rebellion (crimen de rebelión), conspiracy to commit a crime (concierto para delinquir), terrorism, public road obstruction, attempted homicide, etc. Environmental defenders have been particularly affected and criminalized for their participation in peaceful assemblies against extractive and business projects for the defence of the environment" (Forst 2018, 11-12).

10 PCN, or Proceso de Comunidades Negras, or Black Communities Process is the largest black social movement organization in the Colombian Pacific region.
} 
social indicators like infant and maternal mortality, poverty, and life-span (RodríguezGaravito et al. 2008). Further, Afro-Colombian women are targeted at the intersections of race and gender, subject to sexual violence as a systematic weapon of subjugation (Inter-American Commission on Human Rights (IACHR) 2006, Report on Violations of Women's Human Rights, 2010, European Center for Constitutional and Human Rights et al. 2017).

Temístocles Machado played a vital role in the community as a long-time PCN member, a major figure in the May 2017 minga, or civic strike, in Buenaventura, which constituted a 20-day long protest against the expropriation of land by multinational companies. He had played a key role in organizing collective demands to the national government to improve local access to resources such as "public education, welfare, healthcare, and better agricultural support" (Carrillo 2018). These activities rendered him one of the city's most threatened social leaders, and despite reporting the threats he was receiving, he received no protection from the police or any other state entity (Carrillo 2018). The context in which his death took place is no anomaly, but an increasingly occurring phenomenon. Human rights work in general is viewed by the Colombian Government as an impediment to state and corporate interests: where economic profit expansion is understood through the liberal ethos of late capitalism as national progress, human rights work is deemed antithetical to national security. Human rights leaders, especially those committed to land reform and restitution struggles, have often been named by the state as communists and/or terrorists, placing them at the center of counterinsurgency strategies and the less official operations of parastate and "gun-for-hire" criminal organizations.

What is striking about Machado's death, is that he had amassed almost four decades worth of materials evidencing the systematic violence perpetrated against vulnerable communities in order to steal their land. His collection of photographs, pamphlets, and documents was impressive enough to compel the Centro Nacional de Memoria Histórica (National Center of Historical Memory) to digitize his archive, as it was deemed at great risk for disappearing due to the threats Machado had been receiving for a long time (Carrillo 2018, and Ciurlizza 2018). The destruction and elimination of research, knowledge, and archives built by subaltern populations documenting human rights abuses has long been a strategy attending state-national production of Official History that systematically builds itself off the denial of histories otherwise. In the wake of human rights abuses, there is a collective "archival imperative" to preserve documentation countering the strategies of denial, misinformation and national gaslighting that are part of the governance of the flow of information and knowledge providing evidence of state accountability for such abuses. Without original documents, it is difficult to disprove "future claims by revisionists who seek to mitigate the intensity or scope of past events" or to allow future generations "to thoroughly investigate what happened and reach their own conclusions" (Bickford 1999, 1099-1100). Of particular concern to Machado's documents and the collective memory they represent, is the 2018 resignation of Gonzalo Sánchez from his position as Director of the National Center for Historical Memory $(\mathrm{CNMH})$, which he has been with since its inception in 2011 (Orozco Tascón 2018). Victims' groups across the country have consistently disapproved of President Duque's string of right-wing selections for the new leadership of the organization, including the current Director, Darío Acevedo, whose previous public record entails a refusal to 
recognize the armed conflict as official history as well as claims that the JEP is a FARCcontrolled project acting against the Colombian military. ${ }^{11}$ Acevedo has stated a commitment to upholding the Victims' Law (under which the CNMH was established), and to ensuring the protection of the CNMH's archives and prioritizing victims' testimonies. But numerous civil society organizations and victims' rights groups have denounced him as the choice for this role, and have expressed concern about his ability to pursue the work of the CNMH with impartiality and objectivity (Alsema 2018a, 2018b, Semana 2019a, 2019b, Justicia y Redacción APP 2019). ${ }^{12}$ At the time of this resignation, Gonzalo Sanchez expressed concern about the CNMH being taken over by those who might set aside its commitment to research for civil society and victims' right to truth, and turn it into an instrumentalized tool in the politics of truth and history (Orozco Tascón 2018).

What's more in regard to memory and truth, the Colombian State has refused to investigate the ongoing targeting of human rights defenders. It has explicitly denied that there is any pattern of killings or targeting of community leaders in the country - despite documentation that leaders are being targeted specifically for their organizing for land restitution and victims' rights, including their participation in and support of the peace process and its truth-seeking mechanisms (Carmel 2018, UN Human Rights 2019). Of no less concern are ongoing efforts to impede access to truth, most recently evident in the military's restriction of the Colombian Truth Commission's access to important records (Moreno Barreto 2018). The Colombian Commission for the Clarification of the Truth, Coexistence and Non-Repetition ("Truth Commission") was formally launched November 29, 2018, as an extrajudicial, eleven-member team with a three-year mandate to investigate the conditions and effects of the conflict, and to document the human rights violations that have taken place. ${ }^{13}$ Intended to ensure the Right to Truth for Colombia's civil society, from its inception the Truth Commission has been contending with efforts by the Colombia Armed Forces to block its progress, as well as with a smear campaign aimed at delegitimating the Commission's president, human rights advocate Father Francisco de Roux (National Security Archive 2018, Semana 2018). Additionally, in February 2019, current President Ivan Duque defunded the Truth Commission's budget by $40 \%$, adding further barriers to its ability to thoroughly document and establish a collective history of the armed conflict and the human rights abuses that have been so central to victims' experiences (Alsema 2019). Indeed, the mere recognition that an armed conflict has been taking place was persistently denied by the Colombian government for at least eight years under the presidency of Álvaro Uribe (2002-2010), whose right-wing policies and rhetoric spread the notion that Colombia's public was actually under terrorist attack, rather than embedded in a context of decades long insurgency and counter-insurgency warfare. While President Santos' recognition of the armed conflict may have opened the way toward the establishment of peace negotiations

\footnotetext{
11 The first two choices for President Duque, which were ultimately rejected, were Mario Javier Pacheco and Vicente Torrijos.

${ }^{12}$ For a copy of the letter submitted by a coalition of victims' groups, rejecting the selection of Acevedo to the position, see Macías 2019.

${ }^{13}$ The Truth Commission is one of the three key bodies established out of the Peace Accords, along with the Special Jurisdiction for Peace (JEP) in charge of prosecuting human rights abuses; and the Missing Persons Search Unit tasked with investigating more than 80,000 cases of enforced disappearance (Armario 2019).
} 
and transitional justice mechanisms, the blockage of open access to information that might contradict the Official Truth remains a significant concern. Subaltern archives of knowledge that chronicle local histories otherwise constitute a threat to the governmentality of the state knowledge/power apparatus, as well as the state's ability to represent itself as a viable democracy in its public efforts to achieve vetted status in the global economic and political arena. ${ }^{14}$

It is here I want to mark Official History as an apparatus of knowledge/power central to governmentality, which itself upholds and is upheld by what Sylvia Wynter has named the "coloniality of being/power/truth."15 I want to pay particular attention to the temporal relation between Official History and what we could call "Official Future" the telos of nationalist-capitalist progress, or a pre-determined boundedness to contemporary late liberal manifest destinies, futures designed by and for the statesanctioned, white/European/American/Western-inspired, heteropatriarchal, bourgeois dream that is persistently contoured by and through coloniality in its material and symbolic formations, and which relies on total epistemic and physical violence. Indeed,

... political leaders have frequently sought to emphasize the future, operating according to the logic of 'transitions to democracy' or 'pacted transitions' and compromising on contentious issues in their attempts to build stable democratic institutions. Furthermore, they have often done so at the expense of remembering the past. (Bickford 1999, p. 1100)

It is only in this linearity of past, present, and future, marked by distinct temporal events constituting history, that such pacted transitions assume temporal succession and necessitate departure from the past in order to move into the future. To submit to and comply with the forgetting required by Official History's narratives is a prerequisite for national belonging in the Official Future that will ensue. Under a temporal regime that requires efficiency, lingering on the conflict-ridden past in order to seek restitution is seen as infantile attachment and self-victimization, a refusal to responsibilize one's self toward the greater "common good." 16 Truth, justice, and memory work are a legal and

\footnotetext{
${ }^{14}$ Foucault's notion of power/knowledge suggests that power is shaped by and produces knowledge; and that knowledge is itself never neutral, but contours relations of power, where power is understood not as subjugation, domination, sovereignty of the state, or the law, but a series of complex and polyvalent relations of force circulating forms of knowledge as truth, which in turn, consolidate power's disciplinary and productive-subjectivating impact. There is, in short, a political economy of a will to knowledge, in which knowledge is both an effect and a strategy of power. See Foucault 1978, 92-102.

${ }^{15}$ In naming this concept, Wynter invokes the work of Aníbal Quijano, Walter Mignolo, and others, to elaborate on the epistemic disregard and demonization of indigenous ways of knowing that was central to the consolidation of western forms of knowledge which initiated the concept of colonial difference (with race as a major nexus) and worked to secure the western bourgeois idea of the human (Wynter 2003).

16 Sovereignty, according to Foucault, was only legitimate insofar as its end purpose was "the common good and salvation for all." But the "common good" only "... exists when all subjects obey the law without fail, perform their appointed tasks well (...) and respect the established order (...)" (Foucault 2007, 98). The shift from modes of sovereign power toward the arts of governing, which Foucault specifies as the modern form of state power are no less imbued with the traces of sovereignty as an objective of the self-governing liberal subject. Late liberal governmentality imposes onto the individual the measure of legitimacy through the subject's capacity to self-regulate, and responsibilize toward forms of self-making aligned with that same definition of the "common good." In its contemporary form, the state of government enforcing that common good takes the population as its territory of regulation, with maximization of the capitalist economy as its science and mode of salvation, and with militarized and diplomatic operations as its central apparatuses of security.
} 
social hindrance to moving forward and allowing so-called peacetime to organize daily life to maximize national wealth.

Further, the claims of movement toward peace, security, economic prosperity, of progress for all, not only position the state paternalistically in relation to Colombia's subaltern groups who abide by non-wage, small-scale, and subsistence economies, but elide the forms of violence against those groups that constitute the very conditions of possibility for "peace" as economic security. For small-scale peasant farmers, AfroColombians, and indigenous communities, the conflict remains very much in duration, an enduring concern. The temporal relation between Colombia's Official History (the armed conflict as one of insurgency/counter-insurgency, a war on terror) and Official Future (economic prosperity, foreign investment, extractivism, the dividends of peacetime) is represented, in part, in what Mark Rifkin has called "settler colonial temporality" wherein

... the shared modernity or presentness of Natives and non-natives implicitly casts Indigenous peoples as inhabiting the current moment and moving toward the future in ways that treat dominant non-native geographies, intellectual and political categories, periodizations, and conceptions of causality as given - as the background against which to register and assess Native being-in-time. (Rifkin 2017, p. viii)

Though Rifkin is speaking specifically of indigenous temporal difference in the United States, the development of the Colombian Nation-State since its inception has both modelled itself off of, and been influenced by the US. No less important, the proliferation of economic policies under globalization's more recent manifestations reflects the coloniality of power and its ever-unfolding rhizomatic forms, which are so often rooted in US machinations of the global juridical-economic sphere. ${ }^{17}$ There is an ontoepistemological temporal alterity to indigenous and black Colombian life as well, which is also measured against neoliberal and settler colonial timescales and conceptions of causality, history, and future.

Rifkin's work is relevant in the Colombian context, for thinking through the specificities of how Colombian indigenous and black life practices also "appear as a blockage, as a drag on or diversion from a trajectory shaped by the orientations and momentum of settler colonial imperatives" (Rifkin 2017, p. 99). The imposition of settler colonial temporality as a militarized apparatus of governmentality enforcing a particular temporal conduct includes the insistence on assimilating black Colombian history into dominant national periodization schemes, the reorganization of life into increasingly privatized modes, and insertion into the market and wage economy which includes a willingness to subject ancestral lands to damaging extractivist modes of production. Non-compliance is met with threat, and perhaps the funneling of black Colombian assertions of difference through a language of rights, can be seen complexly as a strategic challenge to the state through means recognizable to it, "while at the same time seeking to mark the limits of settler-state authority" (Rifkin 2017, p. 180). ${ }^{18}$ Given the

\footnotetext{
17 This is not to suggest a sameness in the genealogies of US and Colombian subjugation of subaltern peoples and their temporal apparatuses of power-knowledge, but to point to what Lisa Lowe has called "the intimacies" of continents - the interlocking residual and emergent forms of governance and political economy that flow across seemingly distant geographies and epochs (Lowe 2015).

${ }^{18}$ Rifkin's elaboration on temporal sovereignty complexifies subaltern engagement with rights mechanisms as not a purely assimilative endeavor (Rifkin 2017, 179-180). Though I do not address the concept of
} 
contemporary politics of violence that contour black life toward forms of deathboundedness, in Colombia, and globally, there is an imperative to pursue formations of freedom and justice articulated in their specificity by black communities - in part, through human rights mechanisms as crucial to the system that is the primary available modality of upholding access to the resources that rights afford. But this also requires critical navigation between refusing enforced assimilation into the western, liberal, individual conceptualizations of the universal human, and what might be deemed strategic, provisional assimilation into that subject-formation toward political ends.

In Territories of Difference: Place, Movements, Life, Redes, Arturo Escobar (2008) delineates a series of problems identified in relation to the politico-organizational principles of the Proceso de Comunidades Negras de Colombia (PCN/Black Communities Process of Colombia). ${ }^{19}$ The guiding principles include the following:

1. The "right to being black" in the principle of the reaffirmation of identity: that blackness retain the "cultural logic and lifeworld (cosmovisión) in all of its social, economic, and political dimensions." Intrinsic to this are the valuations such cultural logics attribute to black life, against "the great lie of the logic of domination" that upholds hierarchies of value devaluing black life, and expressing that devaluing through subjugation and exploitation.

2. The "right to the territory (as the space for being)" converges land rights and claims to lifeworlds, as ancestral territory is understood to be a necessary condition for onto-epistemological, and socio-cultural cultivation and expression. The intimacy and harmonization between historically constituted "space for living in accordance" with what black communities "think and desire as a form of life" demarcates the right to territory as not merely a question of property, but of the sustenance and sustainability of the diverse articulations of black life that cannot be encompassed by the cohesive, homogenizing boundaries of identity-based politics.

3. The "right to a distinct vision of the future" or to constructing an autonomous perspective of the future, is a stand for "economic and social development based on" Afro-Colombian culture and traditional forms of production and social organization. The conception of autonomy named here, against western, liberal autonomy of the individuated subject, is one which I read as staking a claim in the distinct lifeworlds of the Black Pacific and the cultural and

\footnotetext{
sovereignty in this essay, it remains a major factor in understanding the juridical limits and possibilities for subaltern populations to make claims and self-organize politically in relation to the state and its governing strategies. Rifkin's chapter titled Deferring Juridical Time $(2017,179-192)$ offers some vital reflections on the matter as framed in Indigenous Studies.

19 See Table 5, titled Analysis and Strategies of the Black Women's Network for Black Women and the Black Communities of the Pacific (Escobar 2008, 243-246). I read the problems and principles in this chart as representative of two important kinds of knowledge making vital contribution first and foremost to their own communities processes of justice, but also to Black Studies and Legal Studies. In so far as the forms of right that are being articulated circulate within already institutionalized legal parameters, as well as outside of them, I suggest that the imaginative capacity of some of these principles contour possible future configurations of rights that could find purview under the protection of the law, without necessarily reproducing the need for the liberal sovereign subject of right. The logics underlying these articulations of rights both press the imagination to expand into the yet unthought of law's capacity, and press the limits of law itself, against its own force.
} 
temporal logics organizing social, political, and economic relations. Notably, it also includes a right to collectively define for themselves, how to configure the relationships between the black communities, the state, and the rest of society.

4. The right to be part of, and participate in, the struggles of black people throughout the world, as an articulation of solidarity to "alternative life projects" as well as of the relevance of local specificity of political labor to both national and international efforts (Escobar 2008, 223 and 245). ${ }^{20}$

I read these as strategically separate claims that in their reflection of black Colombian modes of life represent an ecology of relations that constitute collective and individual self-making through particular local organizations of space and time. The specific sociality and chrono-logics of black life are intimately tied to place, cultural practice, and relationship, and exceed the grasp of late liberal timescales. For example, river settlement communities whose everyday is guided by the "logic of the river" in which the aquatic terrain is a space that constitutes family, wider social relations, and processes of meaning-making and worldbuilding. The mega-development-based destruction of the river, and the forced displacement harnessed by militarized groups to clear territories for those projects under the guise of securitization, not only ruptures access to subsistence-based ancestral practices like fishing and mining, but thusly deracinates people from their temporal and onto-epistemological referents (Escobar 2008, p. 221).

As Escobar has shown, the construction of black ethnic identity in Colombia arose through contentious struggles and formations of law that, through the 1980s and 1990s, brought into being the "black political subject" as a politico-organizational figure and identity in unprecedented ways. But, he claims, the process through which this identity came into being has not purely been one of an assimilation or subsumption of a historically differentiated subject into the confines of the universalized, liberal, individual, possessive subject of right. What I name here as the "chrono-logics of the otherwise" aims to foreground the temporal alterity permeating black Colombian epistemologies as a unique order of difference through which the politics and poesis of black lifeworlds and cosmovisiones pose possibilities for black existence not perpetually subject to or defined by Western/Gobal Northern/dominant epistemologies and their attendant temporal regimes.

The right to a distinct vision of the future, as a major principle of the PCN, challenges the mechanisms of knowledge/power by which governance maintains its grasp on spatial and temporal conduct. Capitalistic conquesting of property, is brought into question, as is the property relation itself in a less overt form than during the Trans-Atlantic Slave Trade, but in a form that no less attempts to enforce blackness as a position bereft of autonomy over any present and future. How does that which is past but not past, the afterlife of slavery's ontological and epistemological infrastructure, persist in what Ronak K. Kapadia has called the "the dystopian here and now of settler colonial rule"? (Kapadia 2017) How has the future itself been rendered property to which rights may or may not be claimed?

\footnotetext{
${ }^{20}$ For greater detail, see all of chapter 5 in Escobar 2008.
} 


\section{Litigating the future and the right of generations to come in the Colombian} Amazon

A historic ruling that took place in April 2018, for the government to stop all deforestation of the Amazon and address climate change, connects rights of nature as legal entities with the rights of future generations of communities whose very subsistence and lifeworlds are tied to those environments. On January 29, 2018, with the aid of Dejusticia, a research and advocacy organization, twenty-five youth from 17 cities across Colombia, ranging from ages seven to 26, brought a lawsuit against the Colombian government. ${ }^{21}$ After a 44 percent increase in deforestation amounting to "178,597 acres of forest loss, of which 39\% was concentrated in the Amazon region" between 2015 and 2016, "the plaintiffs had said the government's failure to stop the destruction of the Amazon jeopardized their futures and violated their constitutional rights to a healthy environment, life, food and water" (Moloney 2018). ${ }^{22}$ Further, the litigants "demand that the government creates [sic] an inter-generational agreement on climate change - taking into account impacts on future generations" (Bustos 2018).

While climate change litigation is on the rise globally, the Supreme Court decision was the first favorable ruling of its kind in Latin America, and is precedent-setting internationally, positing possibilities for strategically litigating the future. ${ }^{23}$ The April 2018 ruling recognizes the Colombian Amazon as an "entity subject of rights" granting the forest legal personhood - a rising trend in environmental justice. ${ }^{24}$ Developed in consultation with the Juliana $v$ United States case, both cases are organized around groups of youth making claims based on the could-be futures lived under climate change and the capacity of the planet to sustain diverse human life, documented in relation to presentday effects of climate change on each individual plaintiff's life and health. ${ }^{25}$

This approach has helped both groups overcome one of the biggest difficulties in climate-related litigation: proving damage to a specific person, and then arguing that someone is liable for that damage. (Yeo 2018)

The decision gave the Colombian government and the Ministries of Environment and Agriculture four months to present a plan to combat deforestation and "create an intergenerational pact for the life of the Colombian Amazon" with participation of multiple constituents in order to completely eliminate deforestation and reduce greenhouse gas emissions, the latter of which, in Colombia, are primarily caused by

\footnotetext{
21 "Dejusticia is a Colombia-based research and advocacy organization dedicated to the strengthening of the rule of law and the promotion of social justice and human rights in Colombia and the Global South. We promote positive social change by producing rigorous studies and fact-based policy proposals; carrying out effective advocacy campaigns or litigating in the most impactful forums; and designing and delivering education and capacity-building programs"' (Dejusticia 2018c). For the original filing, see Dejusticia 2018a.

${ }^{22}$ Deforestation in Colombia is largely due to cattle ranching, legal and illegal mining, and agricultural expansion (Bustos 2018).

23 For the official ruling, see Sentencia 4360-2018 de la Corte Suprema de Justicia de la República de Colombia 2018.

${ }^{24}$ Other examples of strategic legal personhood allocated to non-human entities include to corporations; the Ganges and Yamuna rivers of India; the Whanganui River and Te Urewera National Park of New Zealand; Colombia's Atrato River; as well as, in the case of Ecuador and Bolivia, nature writ large; and in other efforts, dolphins and higher primates (Institute for the Future 2011, Vidal 2011, Rousseau 2016, McCarthy 2017, Villa 2017).

${ }^{25}$ For more on Juliana $v$ United States, see Juliana et al. $v$ the USA et al. (2015).
} 
deforestation, and are the principal underlying factor in rising temperatures and climate change in the $20^{\text {th }}$ century (Dejusticia 2018d). ${ }^{26}$

The Court's decision was notable, not only in its commitment to holding the government accountable for ongoing effects of climate change that are damaging to diverse forms of life and cultural practice, but in the insistence on the right to healthy and sustainable futures on this planet. The latter concern is maintained both in the rights of presentlyalive younger generations who will be the ones facing the wide range of environmental injustices arising out of climate change in the next 50-70 years, as well as in the right to life for future generations not-yet in existence. The Supreme Court's central conclusions include that:

Deforestation in the Amazon causes imminent and serious damage to all Colombians of present and future generations, as it leads to rampant emissions of carbon dioxide into the atmosphere, producing the greenhouse effect, which in turn transforms and fragments ecosystems, and alters the water resource.

The increasing deterioration of the environment is a serious attack on current and future life and on other fundamental rights; it gradually depletes life and all its related rights.

The inability to exercise the fundamental rights to water, to breathe pure air, and to enjoy a healthy environment is making Colombians sick. It also increases the lack of fresh water and decreases the ability to enjoy a dignified life.

The protection of fundamental rights not only involves the individual, but implicates the "other." This includes the unborn, who also deserve to enjoy the same environmental conditions that we have.

Without an equitable and prudent framework of consumption, the future of humankind may be compromised due to the scarcity of essential life resources. Solidarity and environmentalism are 'related until they become the same.'

We are all obligated to stop exclusively thinking about our self-interest. We must consider the way in which our daily actions and behaviors affect society and nature. (Dejusticia 2018d)

The ruling was a historic one, and a radical reconfiguration of rights at the intersection of the law and material realities that have been otherwise influenced by a distinct metaphysics of self. The insistence on the right to life and conditions of livelihood for not-yet born generations intervenes on the liberal individuation and settler colonial temporality upheld by and infusing the law and its figurations burdened with the particular and alienated liberal mandate of responsibilization, which renders every person only accountable to themselves, and views the metaphysics of selfhood as contained to western, bourgeois measurements of what constitutes a lifetime. ${ }^{27}$ In other

\footnotetext{
${ }^{26}$ Not surprisingly, a year later, the Colombian government had failed to fulfill the Court's order, and deforestation has actually increased (Ardila Sierra 2019). It is beyond the scope of this paper to address this failure in-depth but foregrounds ongoing concerns about the utility and benefit of rights-based claims as opposed to other kinds of claims.

27 Rooted in bootstraps mythologies and its particular thread of now-widely-exported US-American individualism, dominant culture is permeated by the idea that even in "natural disasters" a person's ability to survive is not a condition of their historically-produced social, economic, and political vulnerability, but a sign of their resilience and capacity for innovative strategy. As Wendy Brown $(2015,131-134)$ has noted, it is a devolution of state responsibility toward its smaller and weaker contingencies. It includes the import
} 
words, under settler colonial temporality and its manifestations under late liberalism, responsibility for conduct is measured insofar as one has maximized their profitability for capital. The afterlives and effects on social and environmental ecologies that extend beyond the individual lifetime are not given import. The reconfiguration of rights as intergenerationally affected poses a chrono-logics that counters this framework.

An amicus brief submitted by James E. Hansen, Director of the Program on Climate Science Awareness and Solutions of the Earth Institute at Columbia University and previously the top climatologist at the National Aeronautics and Space Administration reads:

Significant impacts from human-induced climate change are already experienced in Colombia and other nations - from sea level rise, hydrological change, increased heat, amplified severe weather, altered pathogens, and related disruptive factors. But those and other impacts will become extreme, if climate change remains essentially unarrested. Far worse is still to come. Plaintiffs, and the future generations for which they ineluctably must stand, will be disproportionately burdened, stressed, tested, and harmed. (Dejusticia 2018b)

Recognizing the interconnectedness of solidarity and environmentalism as two threads of the same political necessity, the ruling and its submitted arguments further acknowledged that environmental impacts of greenhouse emissions exacerbates the exposure of vulnerable populations to violence. What's more, the continuation of unsustainable forms of industry and production threatens futures that will be rendered impossible or obliterated in their wake. In this sense, global carbon production is also framed not purely as an environmental hazard damaging to the ecosystem, but a human rights abuse that once unleashed as a phenomenon does not have a predictable and singularly causal endpoint, but will continue to be a human rights abuse as subsequent generations after generations will be subject to the environmental injustices yielded. It thus shifts the temporal framing of responsibility, and therefore, too, of the ecology of relations. It poses an imaginative strategy for litigation, and aligns diverse ontological and epistemic lifeworlds through defending the dreams and needs of communities across Colombia, as represented by the twenty-five indigenous, black, and mestizo youth that brought the lawsuit with the aid of Dejusticia. The right to sustainable futures as a right that, for the not-yet-in-existence descendants of present-day living human life is contingent on a chrono-logics otherwise, refuses the mandates for temporal conduct under settler colonial temporality and its modes of governance and subjectivation which place capitalist production above sustainable futures.

\section{Conclusion. Chrono-logics otherwise: The future out of bounds}

This paper has contrasted three different epistemologies of futurity in the context of Colombia's post-Peace Accord era. It laid out a brief analysis of the state imaginary of Colombia's future as one in which economic prosperity defined by and reached through governmentality and its temporal conduct of conduct under late liberalism takes primacy over all else as the raison d'état. It then elaborated two distinct challenges to the

of moral burdening of vulnerable populations to adapt through human capitalization, tasking them to take on "strategies of self-investment and entrepreneurship for thriving and surviving" and "measuring, remaking, and reorienting" themselves toward the order of neoliberalism. 
state's settler colonial temporality that circulate in subaltern Colombian life to pose futures otherwise. Both strategically use a framework of rights to make claims to the future as a vital element in the ecology of relations that constitute their ontoepistemological alterity, which intimately contours daily material life. In the context of the black Colombian Pacific and the black social movement, the PCN, the right to a distinct vision of the future is interdependent on rights to territory as both a right to individual and collective lands as well as a right to space for being; ancestral and cultural practices that include non-capitalist economic formations; identity, and ways of knowing; and a right to difference itself. With the litigation pursued by 25 youth in collaboration with the organization Dejusticia, the right of both present and future generations to life and health was used to make claims that succeeded in the historic ruling demanding the stoppage of deforestation in the Colombian Amazon. Acknowledging the ecology of relations which ties present generations to those to come, the arguments posed by these youth display a complex onto-epistemological alterity, employed as solidarity within the diversity of the group's geographical and cultural composition. Both the PCN and the Dejusticia lawsuit unsettle the liberal capitalist ethos of governmentality and its anchor in atomistic individualism, making rights-based claims to a future other than that set out by capital's aims.

The racial grammar underlying the relation between Official History and Official Future comports daily national life to necessitate the death-boundedness of its "Others": nonwhite, non-state-sanctioned (no less of state-threatening) bodies and worlds whose histories otherwise are intimately woven with futures otherwise, futures other than what the secular-Christian, colonial, capitalist telos has configured for all.28 By futures otherwise, I indicate both the sense of temporal belongings that do not conform to dominant, western, linear space-time configurations and their attendant politics, aesthetics, and ethical horrors, as well as in the sense of naming to what one is bound to life, movements, assemblages, imaginations, practices, and onto-epistemologies otherwise.

In the Afro-Colombian context, the grammars of onto-epistemic disobedience underlying the relation between histories and futures otherwise refuse the racialized status of the ontological death rooted in the historical objectification of blackness as property. The grammars of disobedience also refuse the telos of material, cultural, and social death (whether by forced assimilation into capital's governmentality, or by obliteration) that seeks to discipline black existence in the service of its own demise. It is to say and enact that "our future will not be deathbound, but will flourish."

The lawsuit and Supreme Court decision to halt deforestation of the Amazon strategically employ an object-oriented ontology, giving rights of personhood to the forest itself. Further, it diminishes the hold the state has on the future as a kind of property ripe for expropriation from the commons and subsequent commodification and speculation. The grammars of onto-epistemic disobedience fueling these two approaches underscores the relation between histories and futures otherwise in their refusal of the commodified status and historical objectification of nature and time as

${ }^{28}$ By death-boundedness, I refer to Abdul JanMohamed's definition of "the death-bound subject" as one whose social and physical existence is "formed from infancy onward by the imminent threat of death" (JanMohamed 2005, 2). 
property - a phenomenon that has been intimately linked with histories of racial and gendered objectification and subjugation.

These chrono-logics otherwise infuse political action as a kind of temporal flight from the hold of settler colonial temporality. In this sense, I read these movements as articulating their futures through what Tina Campt has named as the future-realconditional "what will have had to have been" (Campt 2017, p. 114) against the Colombian State's institutionalization of violence as Official Future. ${ }^{29}$ The violence upheld through the onto-teleological and grammatical future-simple mandate of late liberal coloniality's present-day manifest destiny, is the already pre-figured "what will happen" refused and disassembled in and by diverging and disobedient temporalities.

Attending to the chrono-logics inhered in the western model illuminates an intimate propinquity between the law and the temporal regime it upholds. In the black Pacific Colombian articulations of rights as onto-epistemological principles that include a right to a distinct vision of the future, and in the historic Dejusticia case litigating the future, as a chrono-logics otherwise, a claim can be made for the radical potential for conceptualizations of right, law, temporality, and metaphysical orderings of the world to be transformed by the deep alterity they represent. The threat this poses to the political, material and symbolic grasp of governmentality's aims undermine the temporal regime intimately tied to regimes of violence, citizenship and belonging, and capital accumulation, which harness nationalism, and neoliberal and moral economies that conflate patriotism with acquiescence and assimilation to capital's socio-economic, historical, and temporal imperatives.

The dominant chrono-logics at play are deemed what is logical, uphold the rationality or reason of the state, and rationalize the targeting of human rights leaders by deeming them irrational or insurgent manifestations of an illogic - the proliferation of which must be eradicated in order to preserve the temporal conduct of the nation and its impending "peace dividend." Further, Western linearity and causality discount non-western chrono-logics. The law renders other temporal relations, such as the afterlife of genocide and slavery or the afterlife of extractivist pursuits, immaterial to any account of the trauma faced by communities and ecosystems in their wake. Hence, the chrono-logics upholding the ongoing killing of black and indigenous people, of human rights leaders, deem the event of each death anomalous and independent of each other, rather than patterned expressions of a systematically ordered world of racialized, gendered, and economic violence.

Temístocles Machado's collection of materials was one kind of record that in spanning decades performed documentation of the temporal continuities and discontinuities across nearly half a century. Other kinds of records profuse with denunciation of the ongoing violation and deracination of subaltern bodies and life across the Colombian urban and rural landscapes constitute a historical archive of past, present, and futures. Sensory records of black and indigenous affect and sensation circulate in symbolic and material culture; the transcripts and testimonies engrained in local landscapes corroborate with collective memory regarding what has been and what will have had to have been. The ecologies of nature and culture exceed and contravene the supposed

\footnotetext{
${ }^{29}$ For more on Campt's discussion of black feminist futurity and grammars of time, see also Campt 2017, 17.
} 
divide between the two, registering the entangled existences that enfold through ongoing creative processes generating diverse lifeworlds. Outside the enclosure of the temporal regime of the state, futures otherwise move out of bounds. The future that will have had to have been, is both a now and a not-yet, an urgency of the present, and an undetermined possibility of what is to come.

\section{References}

Alsema, A., 2018a. Duque replaces director of National Center for Historical Memory with radical pundit: reports. Colombia Reports [online], 14 October. Available from: https://colombiareports.com/duque-replaces-director-of-national-centerfor-historical-memory-with-radical-pundit/ [Accessed 15 May 2019].

Alsema, A., 2018b. New director of Colombia government truth body fired from university for lying. Colombia Reports [online], 7 December. Available from: https://colombiareports.com/new-director-of-colombia-government-truth-bodyfired-from-university-for-lying/ [Accessed 15 May 2019].

Alsema, A., 2019. Duque defunds Colombia's Truth Commission. Colombia Reports [online], 20 February. Available from: https://colombiareports.com/duquedefunds-colombias-truth-commission/ [Accessed 15 May 2019].

Antonelli, M.A., 2011. Megaminería, desterritorialization del estado y biopolitica. Astrolabio, Nueva Época [online], nº. 7, 3-22. Available from:

https://revistas.unc.edu.ar/index.php/astrolabio/article/download/592/3171\%2C [Accessed 6 May 2019].

Arboleda, M., 2015. The Biopolitical production of the city: urban political ecology in the age of immaterial labour. Environment and Planning D: Society and Space [online], 33(1), 35-51. Available from: https://doi.org/10.1068\%2Fd13188p [Accessed 6 May 2019].

Ardila Sierra, S., 2019. The Colombian government has failed to fulfill the Supreme Court's landmark order to protect the Amazon. Dejusticia [online], 5 April. Available from: https://www.dejusticia.org/en/the-colombian-government-hasfailed-to-fulfill-the-supreme-courts-landmark-order-to-protect-the-amazon/ [Accessed 15 May 2019].

Armario, C., 2019. Colombia's peace court weighs truth, justice, and mistrust. AP News [online], 9 January. Available from:

https://www.apnews.com/3edc8baf914c49028c327252255c8765 [Accessed 15 May 2019].

Bickford, L., 1999. The Archival imperative: human rights and historical memory in Latin America's Southern Cone. Human Rights Quarterly [online], 21(4), 10971122. Available from: http://dx.doi.org/10.1353/hrq.1999.0048 [Accessed 6 May 2019].

Bilotta, N., 2017. The FARC, land reform, and the future of Colombia's security. Global Risk Insights [online], 1 October. Available from: https://globalriskinsights.com/2017/10/land-farc-future-colombia/ [Accessed 1 May 2018]. 
Brown, W., 2015. Undoing the Demos: Neoliberalism's Stealth Revolution. Brooklyn, NY: Zone Books.

Bustos, C., 2018. New climate change lawsuit in Colombia part of growing, worldwide trend. Open Global Rights [online], 13 March. Available from:

https://www.openglobalrights.org/New-climate-change-lawsuit-in-Colombiapart-of-growing-worldwide-trend/ [Accessed 17 May 2018].

Campt, T., 2017. Listening to Images. Durham: Duke University Press.

Carmel, V., 2018. Colombia: peace crumbles as social leaders killed with impunity. TeleSur [online], 24 November. Available from: https://www.telesurenglish.net/analysis/Colombias-Peace-Crumbles-as-SocialLeaders-Killed-With-Impunity-20180922-0016.html [Accessed 15 May 2019].

Carrillo, K.J., 2018. Colombia's peace process witnesses another death: Temístocles Machado. Amsterdam News [online], 16 February. Available from: http://amsterdamnews.com/news/2018/feb/16/colombias-peace-processwitnesses-another-death-te/ [Accessed 25 April 2018].

Castro-Gómez, S., ed., 2004. Pensar el siglo XIX: cultura, biopolítica y modernidad en Colombia. Bogotá: Pontificia Universidad Javeriana.

Castro-Gómez, S., 2007. ¿Disciplinar o poblar? La intelectualidad colombiana frente a la biopolítica (1904-1934). Nómadas [online], no. 26 (april), 44-55. Available from: http://nomadas.ucentral.edu.co/index.php/inicio/23-teorias-decoloniales-enamerica-latina-nomadas-26/294-disciplinar-o-poblar-la-intelectualidadcolombiana-frente-a-la-biopolitica-1904-1934 [Accessed 6 May 2019].

Castro-Gómez, S., and Grosfoguel, R., 2007. Prólogo: giro decolonial, teoría crítica y pensamiento heterárquico. In: S. Castro-Gómez and R. Grosfoguel, eds., El giro decolonial: Reflexiones para una diversidad epistémica más allá del capitalismo global. Bogotá: Siglo del Hombre / Universidad Central, Instituto de Estudios Sociales Contemporáneos / Pontificia Universidad Javeriana, Instituto Pensar.

Chaparro Silva, A., 2018. "Todas las cosas tienen su tiempo": temporalidad e historia durante la restauración monárquica en la Tierra Firme (1814-1819). Anuario Colombiano de Historia Social y de la Cultural, 45(2), 205-231.

Ciurlizza, J., 2018. The murder of Temistocles Machado: human rights defenders in Colombia are still under threat. Ford Foundation Equals Change Blog [online], 16 February. Available from: https://www.fordfoundation.org/ideas/equals-changeblog/posts/the-murder-of-temistocles-machado-human-rights-defenders-incolombia-are-still-under-threat/ [Accessed 25 April 2018].

Coleman, L.M., 2013. The Making of docile dissent: neoliberalization and resistance in Colombia and beyond. International Political Sociology [online], 7(2), 170-187. Available from: https://doi.org/10.1111/ips.12016 [Accessed 6 May 2019].

Coloquio Latinoamericano de Biopolítica [online], no date. Available from: http://coloquiobiopolitica.com/ [Accessed 31 May 2019]. 
Counter, M., 2018. Producing victimhood: landmines, reparations, and law in Colombia. Antipode [online], 50(1), 122-141. Available from: https://doi.org/10.1111/anti.12358 [Accessed 6 May 2019].

Defensoría del Pueblo de Colombia, 2018. En 2018 han sido asesinados 164 líderes sociales y defensores de derechos humanos [online]. Press release, 13 December. Available from: http://www.defensoria.gov.co/es/nube/comunicados/7706/En-2018-hansido-asesinados-164-1\%C3\%ADderes-sociales-y-defensores-de-derechoshumanos-Defensores-de-DDHH-Cauca-Antioquia-Defensor\%C3\%ADa-delPueblo-Carlos-Negret-Mosquera-1\%C3\%ADderes-sociales.htm [Accessed 25 April 2019].

Dejusticia, 2018a. Acción de Tutela. Tutela Cambio Climático [online]. Bogotá, 29 January. Available from: https://cdn.dejusticia.org/wpcontent/uploads/2018/01/TutelaCambioClim\%C3\%A1tico.pdf?x54537\&x54537\&x 54537 [Accessed 15 August 2018].

Dejusticia, 2018b. Columbia University climate scientist supports climate change litigation case in Colombia. Dejusticia [online], 15 March. Available from: https://www.dejusticia.org/en/climatologo-de-la-universidad-de-columbiaapoya-nuestra-tutela-de-cambio-climatico/ [Accessed 5 August 2018].

Dejusticia, 2018c. Dejusticia: law, justice, society. Dejusticia [online], official website. Available from: https://www.dejusticia.org/en/ [Accessed 17 May 2018].

Dejusticia, 2018d. In historic ruling, Colombian Court protects youth suing the national government for failing to curb deforestation. Dejusticia [online], 5 April. Available from: https://www.dejusticia.org/en/en-fallo-historico-corte-suprema-concedetutela-de-cambio-climatico-y-generaciones-futuras/ [Accessed 12 August 2018].

Echavarría, J.A., 2010. In/Security in Colombia: Writing Political Identities in the Democratic Security Policy. Oxford University Press.

Escobar, A., 2007. La invención del Tercer Mundo: construcción y deconstrucción del desarrollo. Caracas: El perro y la rana.

Escobar, A., 2008. Territories of Difference: Place, Movements, Life, Redes. Durham: Duke University Press.

European Center for Constitutional and Human Rights, Sisma Mujer, and Colectivo de Abogados José Alvear Restrepo, 2015. ICC communication on sexual violence in Colombia [online]. Available from:

https://www.ecchr.eu/fileadmin//uristische Dokumente/Executive Summary EC CHRSismaCAJAR ICCCommunicationVSXinColombia EN.pdf [Accessed 10 August 2018].

Ferreira Da Silva, D., 2010. Towards a critique of the socio-logos of justice: the analytics of raciality and the production of universality. Social Identities [online], 7(3), 421454. Available from: https://doi.org/10.1080/13504630120087253 [Accessed 6 May 2019].

Food and Agriculture Organization of the United Nations, 2016. Rural development is Colombia's peace dividend, President Santos says. News [online], 15 December. 
Available from: http://www.fao.org/news/story/en/item/461047/icode/ [Accessed 5 August 2018].

Forst, M., 2018. United Nations Special Rapporteur on the situation of human rights defenders, Visit to Colombia, 20 November to 3 December 2018. End of mission statement [online]. Available from:

https://www.ohchr.org/Documents/Issues/Defenders/StatementVisitColombia3D ec2018 EN.pdf [Accessed 6 May 2019].

Foucault, M., 1978. The History of Sexuality, vol. 1: An Introduction. Trans.: R. Hurley. New York: Pantheon Books.

Foucault, M., 1983. Afterword: The Subject and power. In: M. Foucault (with H.L. Dreyfus and P. Rabinow, eds.), Beyond Structuralism and Hermeneutics. University of Chicago Press, 208-226.

Foucault, M., 1994. Dits et écrits IV. Paris: Gallimard.

Foucault, M. (with M. Senellart et al., eds.), 2007. Security, territory, population: lectures at the Collége de France, 1977-1978. Trans.: G. Burchell. New York: Palgrave Macmillan.

IberConceptos, 2012. Grupo Temporalidad. IberConceptos Proyecto y Red de Investigación en Historia Conceptual Comparada del Mundo Iberamericano [online]. Available from: http://www.iberconceptos.net/grupo-historicidad [Accessed 15 May 2019].

Institute for the Future, 2011. Strategic personhood, ten year forecast, 2011 perspectives [online]. Available from: http://www.iftf.org/uploads/media/SR1378 TYF11 6Law rdr-1.pdf [Accessed 1 December 2015].

Instituto de Estudios para el Desarrollo y la Paz, 2019. 566 líderes sociales y defensores de derechos humanos han sido asesinados desde el 1 de enero de 2016 - al 10 de enero de 2019 [online]. Available from: http://www.indepaz.org.co/566-lideres-sociales-ydefensores-de-derechos-humanos-han-sido-asesinados-desde-el-1-de-enero-de2016-al-10-de-enero-de-2019/ [Accessed May 15, 2019].

Inter-American Commission on Human Rights (IACHR), 2006. Violence and discrimination against women in the armed conflict in Colombia (OEA/Ser.L/V/II. Doc. 67) [online]. Rapporteurship on the Rights of Women, Organization of American States. Multiple discrimination against Afro-Colombian and indigenous women, section IV, 18 October. Available from:

https://www.cidh.oas.org/pdf\%20files/InformeColombiaMujeres2006eng.pdf [Accessed 10 August 2018].

JanMohamed, A., 2005. The Death-Bound-Subject: Richard Wright's Archaeology of Death. Durham: Duke University Press.

Jaramillo, F. 2017. Colombia is becoming Latin America's brightest star. Miami Herald [online], 24 August, Op-Ed. Available from:

https://www.miamiherald.com/opinion/op-ed/article169028737.html [Accessed 17 May 2018].

Justicia y Redacción APP, 2019. Acevedo, el negacionista del conflicto que dirigirá Memoria Histórica. El tiempo [online], 20 February. Available from: 
https://www.eltiempo.com/justicia/investigacion/presidente-ivan-duque-nombraa-dario-acevedo-en-centro-de-memoria-historica-328730 [Accessed 15 May 2019].

Kapadia, R.K., 2017. Palestine in the Sky: Visionary Aesthetics, Atmospheric Warfare, and the Queer Feminist Utopias of Larissa Sansour. Presentation at the Newberry Library Center for American History and Culture Program Gender and Sexuality Seminar, 10 November.

Kelsey Cascade Rose Juliana et al. $v$ the United States of America et al. Case No. 6:15-cv01517-TC (District Court of Oregon, Eugene Div., 2015) [online]. Available from: https://www.ourchildrenstrust.org/s/YouthAmendedComplaintAgainstUSt9f3.pdf [Accessed 22 May 2018].

Loaiza Cano, G., 2016. Temporalidad, sociabilidad y democracia (Colombia y su siglo XIX). Historia Caribe [online], 11(28), 177-210. Available from: http://dx.doi.org/10.15648/hc.28.2016.7 [Accessed 7 May 2019].

Lowe, L., 2015. The Intimacies of Four Continents. Durham: Duke University Press.

Macías, J.A., 2019. Víctimas rechazan candidato a director de Centro de Memoria Histórica. El Colombiano [online], 4 February. Available from: https://www.elcolombiano.com/colombia/paz-y-derechos-humanos/victimasrechazan-candidato-para-el-centro-de-memoria-historica-OF10154192 [Accessed 15 May 2019].

Maldonado, C.E., 2003. Biopolítica de la guerra. Bogotá: Siglo del Hombre.

Martínez Posada, J.E., 1998. La Universidad productora de productores: Entre biopolítica y subjetividad. Bogotá: Universidad de La Salle.

Martínez Posada, J.E., and Neira Sánchez, F.O., eds., 2009. Miradas sobre la subjetividad. Bogotá: Universidad de La Salle.

McCarthy, J., 2017. India's most polluted rivers are now legally humans. Global Citizen [online], 21 March. Available from:

https://www.globalcitizen.org/en/content/indias-polluted-rivers-now-legallyhumans/ [Accessed 15 May 2018].

McDermott, J., 2014. The BACRIM and their position in Colombia's underworld. Insight Crime [online], 2 May. Available from:

https://www.insightcrime.org/investigations/bacrim-and-their-position-incolombia-underworld/ [Accessed 15 March 2018].

Moloney, A., 2018. Colombia's top court orders government to protect Amazon Forest in landmark case. Reuters [online], 6 April. Available from:

https://www.reuters.com/article/us-colombia-deforestation-amazon/colombiastop-court-orders-government-to-protect-amazon-forest-in-landmark-caseidUSKCN1HD21Y [Accessed 17 May 2018].

Moreno Barreto, J.D., 2018. Los Archivos de inteligencia para reconstruir la verdad. El Espectador [online], 12 July. Available from:

https://www.elespectador.com/colombia2020/verdad-y-memoria/los-archivos-deinteligencia-para-reconstruir-la-verdad-articulo-856887 [Accessed 15 May 2019]. 
National Security Archive (with M. Evans, ed.), 2018. Colombia Truth Commission opens doors, but faces significant barriers to access. National Security Archive [online], Briefing Book \#649, 29 November. Available from:

https://nsarchive.gwu.edu/briefing-book/colombia/2018-11-29/colombia-truthcommission-opens-doors-faces-significant-barriers-access [Accessed 15 May 2019].

Orozco Tascón, C., 2018. "La atmósfera política me obliga a dar un paso al costado": Gonzalo Sánchez. El Espectador [online], 3 November. Available from: https://www.elespectador.com/noticias/politica/la-atmosfera-politica-me-obligadar-un-paso-al-costado-gonzalo-sanchez-articulo-821806 [Accessed 15 May 2019].

Ortega, F.A., 2016. Moral y temporalidad en Colombia (1800-1850). [Vimeo video clip]. Casa de Velázquez [online], 9 May. Available from:

https://www.casadevelazquez.org/en/la-casa/news/moral-y-temporalidad-encolombia-1800-1850/ [Accessed 7 May 2019].

Osorio Granados, M., 2018. Siguen matando líderes sociales, un año después del acuerdo de paz. El Espectador [online], 28 February. Available from:

https://colombia2020.elespectador.com/pais/siguen-matando-lideres-sociales-unano-despues-del-acuerdo-de-paz [Accessed 15 May 2018].

Paschel, T., 2016. Becoming Black Political Subjects: Movements and Ethno-Racial Rights in Colombia and Brazil. Princeton University Press.

Pedraza, Z., 2011. La "educación de las mujeres": el avance de las formas modernas de feminidad en Colombia. Revista de Estudios Sociales [online], nํ․ 41 (diciembre), 72-83. Available from: https://doi.org/10.7440/res41.2011.06 [Accessed 7 May 2019].

Pedraza, Z., 2012. La disposición del gobierno de la vida: acercamiento a la práctica biopolítica en Colombia. Revista de Estudios Sociales [online], nº. 43 (agosto), 94107. Available from : http://dx.doi.org/10.7440/res43.2012.08 [Accessed 7 May 2019].

Pérez González, B., 2014. Biopoder y género: las vidas desnudas de la Guerra. Revista Internacional de Ciencias Sociales Interdisciplinares [online], 3(2), 43-49. Available from:

https://journals.epistemopolis.org/index.php/csociales/article/download/807/375 [Accessed 7 May 2019].

ProColombia, 2018. Eight successful Colombia cities are considered Cities of the Future. Procolombia, Investment News in Colombia [online]. Originally published in Financial Times fDi Magazine. Available from:

http://www.investincolombia.com.co/news/910-eight-successful-colombian-citiesare-considered-cities-of-the-future.html [Accessed 5 August 2018].

Rähme, S., 2018. Frictions in transitional justice processes: Colombia's Victims Law, integral reparation and the temporality of multiple victimization in displaced women. Gobernar: The Journal of Latin American Public Policy and Governance [online], 2(1), Article 6, 33-56. Available from:

https://orb.binghamton.edu/gobernar/vol2/iss1/6 [Accessed 7 May 2019]. 
Report on Violations of Women's Human Rights, in response to the sixth periodic report of Colombia [online]. United Nations, Human Rights Committee, 99th Session, Geneva, 12-30 July. Available from:

https://www.madre.org/sites/default/files/PDFs/1281132395 2010.08.06\%20\%20COLOMBIA \%20SHADOW\%20REPORT\%20ENGLISH \%20FINAL\%20PDF.p df [Accessed 10 August 2018].

Restrepo Espinosa, M.H., 2015. Entre trauma, víctimas y vulnerables biopolítica, desplazamiento forzado Interno y salud pública [online]. Dissertation. Doctorado en Salud Pública. Bogotá: Universidad Nacional de Colombia. Available from: http://bdigital.unal.edu.co/51090/1/mariahelenarestrepoespinosa.2015.pdf [Accessed 7 May 2019].

Restrepo, E., 2004. Biopolítica y alteridad: dilemas de la etnización de las Colombias negras. In: E. Restrepo and A. Rojas, eds., Conflicto e (in)visibilidad. Retos en los estudios de la gente negra en Colombia. Popayán: Universidad del Cauca, 271-299. Available from: https://www.aacademica.org/eduardo.restrepo/53.pdf [Accessed 7 May 2019].

Reuters in Bogotá, 2017. More than 100 human rights activists killed in Colombia in 2017, UN says. The Guardian [online], 20 December. Available from: https://www.theguardian.com/world/2017/dec/20/more-than-100-human-rightsactivists-killed-in-colombia-in-2017-un-says [Accessed 15 March 2018].

Rifkin, M., 2017. Beyond Settler Time: Temporal Sovereignty and Indigenous SelfDetermination. Durham: Duke University Press.

Rodríguez-Garavito, C., Alfonso Sierra, T., and Cavelier Adarve, I., 2008. Racial discrimination and human rights in Colombia: a report on the situation of the rights of Afro-Colombians [online]. Observatory on Racial Discrimination. Bogotá: University of the Andes. Available from: https://www.dejusticia.org/wpcontent/uploads/2017/04/fi name recurso 204.pdf?x54537 [Accessed 25 March 2018].

Rousseau, B., 2016. In New Zealand, lands and rivers can be people (legally speaking). New York Times [online], 13 July. Available from:

https://www.nytimes.com/2016/07/14/world/what-in-the-world/in-new-zealandlands-and-rivers-can-be-people-legally-speaking.html [Accessed 17 May 2018].

Rozema, R., 2011. Forced disappearance in an era of globalization: biopolitics, shadow networks, and imagined worlds. American Anthropologist [online], 113(4December), 582-93. Available from: https://doi.org/10.1111/j.15481433.2011.01371.x [Accessed 7 May 2019].

Semana, 2018. Lo que en verdad dijo el padre Francisco de Roux sobre el ELN. Semana [online], 18 July. Available from: https://www.semana.com/nacion/articulo/lasverdaderas-palabras-del-padre-francisco-de-roux-sobre-el-eln/575740 [Accessed 15 May 2019].

Semana, 2019a. Las víctimas que se oponen al nombramiento de Darío Acevedo en el CNMH. Semana [online], 5 February. Available from: 
https://www.semana.com/nacion/articulo/el-candidato-a-dirigir-el-centro-dememoria-historica-al-que-se-oponen-las-victimas/600242 [Accessed 15 May 2019].

Semana, 2019b. Pese a la polémica, gobierno nombra a Darío Acevedo en la dirección del Centro de Memoria. Semana [online], 19 February. Available from:

https://www.semana.com/nacion/articulo/gobierno-nombro-a-dario-acevedo-enla-direccion-del-centro-de-memoria-historica/601972 [Accessed 15 May 2019].

Sentencia 4360-2018 de la Corte Suprema de Justicia de la República de Colombia, Radicación n. ${ }^{\circ}$ 11001-22-03-000-2018-00319-01. Bogotá, 5 de abril de 2018. Magistrado ponente: Luis Armando Tolosa Villabona [online]. Available from: http://www.cortesuprema.gov.co/corte/wpcontent/uploads/relatorias/tutelas/B\%20MAY2018/STC4360-2018.doc [Accessed 10 August 2018].

Somos Defensores, 2017. Agúzate!: Informe enero - junio 2017. Sistema de información sobre agresiones contra defensores y defensores de DD.HH. en Colombia [online]. Available from: https://somosdefensores.org/wp-content/uploads/2019/05/INFORMESOMOS-DEFENSORES-Enero_Junio-2017 ESPAN\%CC\%83OL.pdf [Accessed 8 June 2019].

Stanford University Mapping Militants Project, 2015. United self-defense forces of Colombia. Mapping Militants Organizations [online], 28 August. Available from: http://web.stanford.edu/group/mappingmilitants/cgi-bin/groups/view/85 [Accessed 25 March 2018].

The Economist, 2017. Colombia's future involves fewer terrorists and more ecotourists. The Economist [online], 6 July. Available from: https://www.economist.com/the-americas/2017/07/06/colombias-future-involvesfewer-terrorists-and-more-ecotourists [Accessed 17 May 2018].

UN Human Rights, 2019. Colombia: "terrible trend" of rights defenders killed, harassed; UN calls for "significant effort" to tackle impunity. UN News [online], 10 May. Available from: https://news.un.org/en/story/2019/05/1038281 [Accessed 15 May 2019].

Vidal, J., 2011. Bolivia enshrines natural world's rights with equal status for Mother Earth. The Guardian [online], 10 April. Available from: https://www.theguardian.com/environment/2011/apr/10/bolivia-enshrinesnatural-worlds-rights [Accessed 16 May 2018].

Villa, L., 2017. The Importance of the Atrato River in Colombia gaining legal rights. Earth Law Center [online], 5 May. Available from: https://www.earthlawcenter.org/international-law/ [Accessed 5 August 2018].

Villegas Correa, I., 2018. Colombia: país fragmentado, temporalidad dividida. Centro de Estudios de Política y Relaciones Internacionales / Universidad Pontificia Bolivariana [online], 11 September. Available from: https://cepri.upb.edu.co/index.php/lineasde-investigacion/gobierno-territorio-y-seguridad/colombia-pais-fragmentadotemporalidad-dividida [Accessed 15 May 2019].

World Bank, 2018. Envisioning the future in Colombia. World Bank [online], 12 February. Available from: 
https://www.worldbank.org/en/news/feature/2018/02/12/anticipar-el-futuro-encolombia [Accessed 17 May 2018].

Wynter, S., 2003. Unsettling the coloniality of being/power/truth/freedom: towards the human, After Man, its overrepresentation - an argument. CR: The New Centennial Review [online], 3(3), 257-337. Available from:

http://dx.doi.org/10.1353/ncr.2004.0015 [Accessed 7 May 2019].

Yeo, S., 2018. How a group of young Colombians successfully sued their government to act on climate. Pacific Standard Magazine [online], 24 April. Available from: https:/psmag.com/environment/young-colombians-sued-their-government-toact-on-climate [Accessed 31 May 2018].

Zakaria, F., 2014. What does Colombia's future hold? Global Public Square, CNN U.S. Edition [online], 7 October. Available from:

http://globalpublicsquare.blogs.cnn.com/2014/10/07/what-does-colombias-futurehold/ [Accessed 5 August 2018].

Zeiderman, A., 2013. Living dangerously: biopolitics and urban citizenship in Bogotá, Colombia. American Ethnologist [online], 40(1), 71-87. Available from: https://doi.org/10.1111/amet.12006 [Accessed 7 May 2019].

Zeiderman, A., 2016. Prognosis past: the temporal politics of disaster in Colombia. Journal of the Royal Anthropological Institute [online], 22(1), 163-180. Available from: http://doi.org/10.1111/1467-9655.12399 [Accessed 7 May 2019]. 